\title{
Editorial: Promoting coastal resilience using green infrastructure
}

\author{
Nigel Pontee \\ $\mathrm{CH} 2 \mathrm{M}$, University of Southampton
}

\author{
Owen Tarrant \\ Environment Agency
}

In this themed issue we present three papers that demonstrate the potential of green infrastructure to enhance coastal resilience. When agreeing to edit this edition of the Maritime Engineering we recognised that there is varied understanding in the meaning of both terms, 'green infrastructure' and 'resilience', in the context of coastal management. We set out the scope of this issue with aim of bringing clarity. We also aimed to help develop further confidence in the application of green engineering approaches amongst the practitioner community, by sharing current international practice and focusing on the engineering performance characteristics of such approaches.

The proliferation of the language used to describe engineering solutions that seek to work with and mimic nature, is indicative of the increasing international ambition to deliver more sustainable shorelines. These aims are evident in Dutch initiatives to 'Build with Nature' (Vriend et al., 2015; Slobbe et al., 2013; Hoek et al., 2012), 'Engineering with Nature' (USACE, 2015) and 'Living Shorelines' (O'Donnell, 2017) in the USA, and the World Bank's recent publication on nature-based flood protection (World Bank, 2017). Key to these approaches are the principles of working with natural process and integrating engineered elements more closely within natural systems. By adopting these principles, not only can the required engineering objectives be achieved, but the environment can be enhanced. Such solutions can potentially have lower whole-life costs and be more adaptable to changing future conditions.

For this edition of the journal, we have adopted the term green infrastructure. Although green infrastructure is a relatively new term, the role of natural habitats, such as beaches, in mediating risk has been recognised by coastal engineers for many hundreds of years (Williams et al., 2016). The risk reduction capacity of other habitats, such as marshes and mangroves, occurred more recently (late 1950s; Salgado and Martinez, 2017), but the real explosion of interest in green solutions occurred after the Indian Ocean tsunami in 2004, Hurricane Katrina in 2005 and Hurricane Sandy in 2012 (Pontee et al., 2017).

Green infrastructure encompasses a variety of approaches including the re-creation of natural habitats (e.g. saltmarshes, mangroves, reefs, beaches, dunes), the enhancement of existing habitats (e.g. foreshore recharge of beaches), the use of more organic materials for structure (e.g. wood rather than stone), the ecological enhancement of existing hard infrastructure (e.g. creation of rock pools within seawalls, or the use of textured concrete to improve colonisation by marine organisms). Green infrastructure elements can be combined with hard structures to form hybrid solutions (e.g. foreshore recharge, marsh restoration and embankment construction). We propose the following working definition of green infrastructure (in the context of coastal management): 'Engineered solutions that mimic the characteristics of natural features, or are closely integrated with natural features, to provide specific services such as wave energy dissipation and erosion reduction. Such solutions may include natural occurring components (e.g. beaches, dunes, saltmarshes, mangroves, sea grasses, coral and oyster reefs) or include engineered structures that are modified to deliver ecological outcomes'.

Resilience is an increasingly preferred strategy when delivering flood and erosion risk management on the coast. As the communities plan for anticipated rises in sea level, they are looking for new ways to ensure that their coastal infrastructure systems are better prepared for possible future extreme events. Strategies that focus on ensuring resilience seem to fit the bill. Coastal resilience is well defined by Rosati et al. (2015) and USACE (2015) as: the system's ability to prepare, resist, recover and adapt to disturbances in order to achieve successful functioning through time.

Flood and erosion risk management solutions that work with, or emulate, nature have the potential to display the desired characteristics of recoverability and adaptability following a disturbance. However, self-recovery to storms, or adaptation to sea level rise, are not certainties. In most circumstances, recovery/adaptation require appropriate sediment supplies and sufficient space (e.g. for gravel or dune barriers to move landwards whilst retaining their alongshore integrity). Enabling such natural processes, whilst desirable, is often limited by the practical reality of a coastline that is already engineered. We therefore urge the engineering and scientific community to 
help practitioners understand where the limits are for these behaviours as well as illustrating the art of the possible. Such dialogue will help put green infrastructure on a similar engineering footing to conventional structural solutions (e.g. sea walls) where the conditions for failure are more widely recognised.

Our first paper by Silva et al. (2017) provides a good overview of the range of different green infrastructure solutions that have been implemented in Latin America. The paper provides some geographic context and covers wetland restoration, dune rehabilitation, use of local timber, creation of green buffer zones and beach nourishment. The paper illustrates how preferred the solution required the careful integration of multiple approaches and helped to deliver additional benefits to local communities over and above flood defence.

Sierra et al. (2017) uses numerical modelling to examine how seagrass meadows on the seabed could potentially reduce wave action and the degree of wave overtopping at two harbours on the Catalan coast of the Mediterranean. The paper cautions that the effectiveness of seagrass in reducing waves is critically dependent on the stem height to water depth ratio, which may limit applicability. The article usefully adds to the growing evidence-base on the effectiveness of coastal vegetation in attenuating the effects of wave energy, which to date, has largely been focused on the role of emergent vegetation (e.g. Vuik et al., 2016; Rupprecht et al., 2017; Anderson and Smith, 2014).

The final paper by Naylor et al. (2017) shows how relatively low cost changes to traditional hard engineering solutions can greatly enhance its biodiversity value. The work presents detailed ecological information to show how the proposed solution performed. The paper concludes with lessons for future schemes. The paper prompts us to consider how such ecological enhancements can be done more routinely in the future.

This leads to a wider debate about the role of green infrastructure solutions. Whilst purists might argue that the greenest approach of all would be to retreat inland, thus lessening the need for defence interventions, such approaches are unfeasible for many of the world's large coastal conurbations. In such situations, the ecological enhancement of structures provides an excellent way of enhancing local biodiversity. Such approaches can also be used to advance seawards, for example by creating ecologically enhanced breakwater/islands. Where there is more space, green infrastructure solutions can combine the dissipative habitats to create wider buffer zones around our coasts.

As outlined above, although the basic value of natural habitats has been appreciated for some time, the challenge for the coastal engineering profession is how to incorporate these features within future designs. In many circumstances, the choice of coastal risk reduction measure may not be an either/or choice between traditional grey infrastructure and nature based approaches, but rather a hybrid of the two.

\section{REFERENCES}

Anderson ME and Smith JM (2014) Wave attenuation by flexible, idealized salt marsh vegetation. Coastal Engineering 83: 82-92.

Hoek V, Ronald M, Brugnach F and Hoekstra A (2012) Shifting to ecological engineering in flood management: introducing new uncertainties in the development of a building with nature pilot project. Environmental Science \& Policy 22: 85-99.

Naylor LA, MacArthur M, Hampshire S et al. (2017) Rock armour for birds and their prey: ecological enhancement of coastal engineering. Proceedings of the Institution of Civil Engineers - Maritime Engineering 170(2): 67-82, http://dx.doi.org/10.1680/jmaen.2016.28.

O'Donnell J (2017) Living shorelines: a review of literature relevant to New England coasts. Journal of Coastal Research 33(2): 435-451.

Pontee N, Beck M, Losada I, Naraya S and Reguero B (2017) Assessing the performance of natural and nature based defences. Proceedings of the Coasts, Marine Structures and Breakwaters 2017 - Realising the Potential, Liverpool, UK.

Rosati JD, Touzinsky KF and Lillycrop WJ (2015) Quantifying coastal system resilience for the US Army Corps of Engineers. Environment Systems and Decisions 35(2): 196-208.

Rupprecht F, Moller I, Paul M et al. (2017) Vegetation-wave interactions in salt marshes under storm surge conditions. Ecological Engineering 100: 301-315.

Salgado K and Martinez ML (2017) Is ecosystem-based coastal defense a realistic alternative? Exploring the evidence. Journal of Coastal Conservation 21(6): 837-848.

Sierra JP, García-León M, Gracia V and Sánchez-Arcilla A (2017) Green measures for Mediterranean harbours under a changing climate. Proceedings of the Institution of Civil Engineers - Maritime Engineering 170(2): 55-66, http://dx.doi.org/10.1680/jmaen.2016.23.

Silva R, Lithgow D, Esteves LS et al. (2017) Coastal risk mitigation by green infrastructure in Latin America. Proceedings of the Institution of Civil Engineers - Maritime Engineering 170(2): 39-54, http://dx.doi.org/10.1680/jmaen.2016.13.

Slobbe E, Vriend HJ, Aarninkhof S et al. (2013) Building with nature: in search of resilient storm surge protection strategies. Natural Hazards 65(1): 947-966.

USACE (United States Army Corps of Engineers) (2015) Use of Natural and Nature-Based Features (NNBF) for coastal resilience. In North Atlantic Coast Comprehensive Study: Resilient Adaptation to Increasing Risk. Engineer Research and Development Center, USACE, Vicksburg, MS, USA. See http://cdm16021.contentdm. oclc.org/cdm/ref/collection/p266001 coll1/id/3442 (accessed 04/01/2017).

Vriend HJ, Koningsveld M, Aarninkhof SGJ, Vries MB and Baptist MJ (2015) Sustainable hydraulic engineering through building with nature. Journal of Hydro-environment Research 9(2): 159-171.

Vuik V, Jonkman SN, Brosje BW and Suzuki T (2016) Nature-based flood protection: the efficiency of vegetated foreshores for reducing wave loads on coastal dikes. Coastal Engineering 116: 42-56.

Williams AT, Giardino A and Pranzini E (2016) Canons of coastal engineering in the United Kingdom: seawalls/groynes, a century of change? Journal of Coastal Research 32(5): 1196-1211.

World Bank (2017) Implementing Nature-based Flood Protection: Principles and Implementation Guidance. World Bank, Washington, DC, USA. 